\title{
UJI AKTIVITAS TABIR SURYA KOMBINASI FRAKSI ETIL ASETAT Annona muricata LINN FOLIUM, Artocarpus champeden SPRENG FOLIUM DAN Plectranthus scutellaroides FOLIUM SECARA IN VITRO
}

\author{
Rachma Nadya Utami, Agung Rahmadani, Mirhansyah Ardana* \\ Laboratorium Penelitian dan Pengembangan Kefarmasian "Farmaka Tropis", \\ Fakultas Farmasi, Universitas Mulawarman, Samarinda, Indonesia \\ *Email: nekkomanekin@gmail.com
}

\begin{abstract}
ABSTRAK
Daun sirsak (Annona muricata Linn folium), daun cempedak (Artocarpus Champeden Spreng folium) dan daun miana (Plectranthus scutellaroides L folium) merupakan tanaman yang telah terbukti memiliki aktivitas tabir surya. Penelitian ini bertujuan untuk mengetahui aktivitas tabir surya kombinasi fraksi etil asetat daun sirsak, daun cempedak dan daun miana secara in vitro serta nilai SPF. Aktivitas tabir surya dan nilai SPF diuji menggunakan spektrofotometri. Aktivitas tabir surya pada 292,5-372,5 nm dan nilai SPF pada 290-320 nm. Hasil penelitian menunjukan perbedaan aktivitas tabir surya pada tanaman tunggal dan tanaman kombinasi yaitu pada tanaman kombinasi memiliki aktivitas tabir surya dan nilai SPF yang lebih tinggi dari pada tunggalnya. Pada tanaman kombinasi daun sirsak, daun cempedak dan daun miana mampu mencapai kategori aktivitas tabir surya tertinggi yaitu sebagai sunblock dan nilai SPF sebagai proteksi ultra
\end{abstract}

Kata Kunci: Asma tidak Terkontrol, Budesonid, Formoterol fumarate dihydrate, metode prospektif, Rumah Sakit Abdul Wahab Sjahranie Samarinda.

\begin{abstract}
Soursop leaves (Annona muricata Lin Folium), cempedak leaves (Artocarpus Champeden Spreng Folium) and miana leaves (Plectranthus scutellaroides L folium) are plants that have been shown to have sunscreen activity. This study ains determine the activity of sunscreen combination fraction of ethyl acetate soursop leaves (Annona muricata Lin Folium), cempedak leaves (Artocarpus Champeden Spreng Folium) and miana leaves (Plectranthus scutellaroides $L$ folium) in vitro and SPF value. The activity of sunscreen and SPF values were tested using a spectrophotometer at 292,5-372,5 $\mathrm{nm}$ and $S P F$ value 290-320 $\mathrm{nm}$. The results showed the different of sunscreen activity on combination plants has sunscreen activity and SPF value higher than sunscreen activity on single plants, combination plants able to achieve highest sunscreen activity category as an sunblock with SPF value ultra protection.
\end{abstract}

DOI: https://doi.org/10.25026/mpc.v6i1.278 


\section{PENDAHULUAN}

Indonesia dikenal sebagai negara tropis dimana pengaruh sinar matahari sangat memberikan dampak terhadap kehidupan manusia. Radiasi ultraviolet yang berlebihan dapat menimbulkan pengkerutan kulit, pigmentasi dan penuaan dini (Agustin, 2013). Dalam jangka panjang radiasi UV dapat menyebabkan perubahan degeneratif pada sel kulit (kanker kulit), jaringan fibrosa dan pembuluh darah yang menuju ke penuaan kulit dini, fotodermatosis dan actinik keratosis (Saha, 2012).

Untuk mencegah efek buruk paparan sinar matahari dapat dilakukan dengan menggunakan tabir surya. Tabir surya merupakan bahan-bahan kosmetik yang secara fisik atau kimia dapat menghambat penetrasi sinar UV ke dalam kulit. Efektifitas tabir surya dinyatakan dengan nilai SPF (Sun Protection Factor). SPF merupakan satuan tabir surya yang dapat digunakan untuk menunjukan waktu berapa lama kita bisa terpapar oleh sinar matahari tanpa kulit jadi terbakar (Sineke, 2016).

Di Indonesia sendiri terdapat banyak tumbuhan yang berpotensi sebagai tabir surya alami. Pada tumbuhan terdapat senyawa fenolik yang berpotensi sebagai tabir surya alami. Senyawa fenolik khususnya golongan flavonoid mempunyai potensi sebagai tabir surya alami karena adanya gugus kromofor yang mampu menyerap sinar UV baik UV A maupun UV B sehingga mengurangi intensitasnya pada kulit (Shovyana, 2015).

Beberapa tanaman telah terbukti berpotensi sebagai tabir surya alami yaitu daun sirsak, daun cempedak dan daun miana. Menurut para ahli pengobatan tradisional dengan penggunaan beberapa tanaman dipercayai dapat memperkuat khasiat dari tanaman tunggal tersebut karena adanya efek sinergis. Kombinasi dua atau tiga tanaman dapat menghasilkan aktivitas yang lebih tinggi (Lingga, 2012). Hal ini didukung menurut Affan (2016) ekstrak sirsak dapat meningkatkan nilai
SPF krim tabir surya kombinasi avembonson dan oktil metoksinamat.).

Penelitian ini bertujuan untuk mengetahui untuk mengetahui aktivitas tabir surya kombinasi fraksi etil asetat daun sirsak (Annona muricata Linn folium), daun cempedak (Artocarpus Champeden Spreng folium) dan daun miana (Plectranthus scutellaroides L folium).

\section{METODE PENELITIAN}

\section{Bahan dan Alat}

Bahan yang digunakan pada penelitian ini yaitu daun sirsak, daun cempedak dan daun miana, metanol, metanol PA, $n$-heksana, etil asetat, air suling.

Peralatan yang digunakan pada penelitian ini yaitu timbangan analitik, rotary evaporator, corong pisah, kuvet kuarsa, spektrofotometer UV Vis, labu ukur, pipet ukur, dan pipet volume.

\section{Penyiapan Sampel}

Sampel yang digunakan adalah daun sirsak, daun cempedak yang berasal dari kota Samarinda dan daun miana yang berasal dari kota Tenggarong. Masingmasing daun kemudian dibersihkan dari kotoran, lalu dicuci dan dipotong-potong kemudian dikeringkan sehingga diperoleh simplisia daun lalu sampel siap diekstraksi.

\section{Ekstraksi dan Fraksinasi Sampel}

Simplisia daun sirsak, daun cempedak dan daun miana diekstraksi menggunakan metode maserasi dengan pelarut metanol 1x48 jam. Hasil ekstraksi di pekatkan menggunakan rotary evaporator hingga diperoleh ekstrak kental lalu difraksinasi cair-cair menggunakan pelarut $n$-heksana dan etil asetat hingga diperoleh fraksi kental Sampel dalam penelitian ini adalah ekstrak hasil fraksinasi dengan pelarut etil asetat. 
Uji Aktivitas Tabir Surya Kombinasi Fraksi Etil Asetat Annona muricata Linn Folium, Artocarpus champeden Spreng Folium dan Plectranthus scutellaroides Folium Secara In Vitro

\section{Uji Aktivitas Tabir Surya dan Nilai SPF Fraksi Etil Asetat Tunggal}

Fraksi etil asetat daun sirsak, daun cempedak dan daun miana masing-masing dibuat larutan stok $1000 \mathrm{ppm}$ dalam labu ukur $100 \mathrm{~mL}$ dan dibuat 9 variasi konsentrasi yaitu $250 \mathrm{ppm}, 300 \mathrm{ppm}, 400$ ppm, 500 ppm, 550 ppm, 600 ppm, 650 ppm, 750 ppm dan 800 ppm dalam labu ukur $10 \mathrm{~mL}$. Diuji aktivitas tabir surya pada $\lambda 292,5-372,5 \mathrm{~nm}$ dan nilai SPF pada 290-320 nm sebanyak 3 replikasi.

\begin{tabular}{lcc}
\hline \multirow{2}{*}{ Kategori } & \multicolumn{2}{c}{$\%$ Transmisi } \\
\cline { 2 - 3 } \multicolumn{1}{c}{ Eritema } & Pigmentasi \\
\hline Sunblock & $<1 \%$ & $3-40 \%$ \\
Proteksi Ekstrak & $1-6 \%$ & $42-86 \%$ \\
Suntan standar & $6-12 \%$ & $45-86 \%$ \\
Fast tanning & $10-18 \%$ & $45-86 \%$ \\
\hline
\end{tabular}

\section{Uji Aktivitas Tabir Surya dan Nilai SPF Fraksi Etil Asetat Kombinasi}

Dibuat variasi perbandingan konsentrasi daun sirsak, daun cempedak dan daun miana yaitu 3:3:2, 2:2:1, 1:2:2 dan 1:1:1 dengan menimbang masingmasing fraksi etil asetat daun sirsak, daun cempedak dan daun miana sebanyak x mg sesuai dengan konsentrasi yang diinginkan dan dilarutkan dengan metanol PA dan dimasukkan ke dalam satu labu ukur $25 \mathrm{~mL}$. Diuji aktivitas tabir surya pada $\lambda 292,5-372,5 \mathrm{~nm}$ dan nilai SPF pada 290-320 nm sebanyak 3 replikasi. Hasil pengukuran absorbansi tabir surya kemudian diolah dengan menggunakan persamaan 1, dan dilanjutkan dengan persamaan 2 dan 3 .

Keterangan:

$$
\mathrm{A}=-\log \mathrm{T} \quad(\text { Persamaan } 1)
$$

$$
\begin{aligned}
& \mathrm{A}=\text { absorbansi } \\
& \mathrm{T}=\text { nilai transmisi }
\end{aligned}
$$

Data T (transmisi) yang diperoleh dapat diolah dengan menggunakan persamaan Cumpelik (1972) untuk memperoleh $\% \mathrm{Te}$ dan $\%$ T. Nilai persentase transmisi eritema dihitung persamaan 2:

$$
\% \mathrm{Te}=\frac{\sum \mathrm{TxFe}}{\sum \mathrm{Fe}}(\text { Cumpelik, 1972) }
$$

Persentase transmisi pigmentasi (Tp) dihitung dengan menggunakan persamaan 3:

$$
\begin{aligned}
& \% \mathrm{Tp}=\frac{\sum \mathrm{TxFp}}{\sum \mathrm{Fp}}(\text { Cumpelik, 1972) } \\
& \text { Keterangan: } \\
& \mathrm{T}=\text { Transmisi } \\
& \mathrm{Fe}=\text { Fluks eritema pada panjang } \\
& \text { gelombang tertentu } \\
& \mathrm{Fp}=\text { Fluks pigmentasi pada panjang } \\
& \text { gelombang tertentu }
\end{aligned}
$$

Setelah diperoleh nilai absorbansi pada panjang gelombang tabir surya dihitung nilai \% transmisi eritema dan nilai \% transmisi pigmentasi Kemudian, nilai \% $\%$ de dan \% Tp dari tiap seri konsentrasi dikategorikan ke dalam Tabel 1, (Balsam dan Sagarin, 1972).

Nilai SPF dapat ditentukan dari nilai absorbansi dari pengujian nilai SPF yang selanjutnya dimasukkan ke dalam persamaan Mansur yaitu :

$$
\mathrm{SPF}=\mathrm{CF}+\sum_{290}^{320} \operatorname{EE}(\lambda) \times \mathrm{I}(\lambda) \mathrm{x} \operatorname{Abs}(\lambda)
$$

Keterangan :

SPF : Spektrum efek eritemal

EE : Efektivitas eritema yang disebabkan sinar UV

I : Spektrum intensitas sinar

Abs : Absorbansi

$\mathrm{CF} \quad$ : Faktor koreksi $(=10)$

Setelah dihitung nilai SPF kemudian dikategorikan sesuai dengan tabel penilaian kategori SPF (FDA, 2013). 


\begin{tabular}{cc}
\hline Nilai SPF & Kategori \\
\hline $2-4$ & Proteksi minimal \\
$4-6$ & Proteksi sedang \\
$6-8$ & Proteksi ekstra \\
$8-15$ & Proteksi maksimal \\
$>15$ & Proteksi ultra \\
\hline
\end{tabular}

HASIL DAN PEMBAHASAN

\section{Ekstraksi Daun Sirsak, Daun Cempedak dan Daun Miana}

Sampel yang digunakan dalam pengujian ini adalah daun sirsak, daun cempedak dan daun miana. Tanaman tersebut masing-masing diambil sebanyak $3 \mathrm{~kg}$. Tanaman ini merupakan tanaman yang sering digunakan oleh masyarakat sehingga sangat mudah diperolehnya. Metode maserasi merupakan metode ekstraksi secara dingin. Tujuan dilakukan ekstraksi adalah untuk menarik senyawa aktif dari simplisia tersebut, Hasil maserasi dengan pelarut metanol selanjutnya di pekatkan menggunakan rotary evaporator. Berdasarkan hasil penelitian rendemen dari ekstrak daun sirsak, daun cempedak dan daun miana secara berturut-turut adalah 4,6 \%, 3,5\% dan $8 \%$.

\section{Fraksinasi Daun Sirsak, Daun Cempedak dan Daun Miana.}

Setalah diperoleh ekstrak kental metode maserasi selanjutnya dilakukan fraksinasi secara cair-cair menggunakan pelarut n-heksana dan etil asetat. Fraksinasi adalah metode pemisahan suatu senyawa berdasarkan tingkat kepolaran. Menurut penelitian Selvi (2008) bentuk gula dari flavonoid akan larut dalam air sehingga aglikonnya akan terekstraksi ke dalam fase etil asetat hal inilah yang mendasari digunakannya fraksi etil asetat sebagai sampel penelitian. Rendemen dari fraksi etil asetat daun sirsak, daun cempedak dan daun miana secara berturutturut adalah $1,4 \%, 0,14 \%$ dan $0,4 \%$

\section{Uji Aktivitas Tabir Surya Tanaman Tunggal Berdasarkan Nilai \% Transmisi \\ Nilai transmisi (T) merupakan} cahaya yang tidak diabsorbsi oleh sampel, cahaya yang diserap diukur sebagai absorbansi (A). Semakin kecil nilai transmisi suatu sampel maka semakin banyak sinar diserap oleh sampel tersebut sehingga dapat dikatakan bahwa semakin kecil nilai transmisi suatu sampel maka semakin baik pula aktivitas tabir surya nya sampel tersebut (Aulia, 2017). Hasil pengujian dapat dilihat pada diagram 1 , diagram 2 dan diagram 3.

\section{HASIL DAN PEMBAHASAN}

\section{Ekstraksi Daun Sirsak, Daun Cempedak dan Daun Miana}

Sampel yang digunakan dalam pengujian ini adalah daun sirsak, daun cempedak dan daun miana. Tanaman tersebut masing-masing diambil sebanyak $3 \mathrm{~kg}$. Tanaman ini merupakan tanaman yang sering digunakan oleh masyarakat sehingga sangat mudah diperolehnya. Metode maserasi merupakan metode ekstraksi secara dingin. Tujuan dilakukan ekstraksi adalah untuk menarik senyawa aktif dari simplisia tersebut, Hasil maserasi dengan pelarut metanol selanjutnya di pekatkan menggunakan rotary evaporator. Berdasarkan hasil penelitian rendemen dari ekstrak daun sirsak, daun cempedak dan daun miana secara berturut-turut adalah 4,6\%, 3,5\% dan $8 \%$.

\section{Fraksinasi Daun Sirsak, Daun Cempedak dan Daun Miana.}

Setalah diperoleh ekstrak kental metode maserasi selanjutnya dilakukan fraksinasi secara cair-cair menggunakan pelarut n-heksana dan etil asetat. Fraksinasi adalah metode pemisahan suatu senyawa berdasarkan tingkat kepolaran. Menurut penelitian Selvi (2008) bentuk gula dari flavonoid akan larut dalam air sehingga aglikonnya akan terekstraksi ke 
dalam fase etil asetat hal inilah yang mendasari digunakannya fraksi etil asetat sebagai sampel penelitian. Rendemen dari fraksi etil asetat daun sirsak, daun cempedak dan daun miana secara berturutturut adalah $1,4 \%, 0,14 \%$ dan $0,4 \%$

\section{Uji Aktivitas Tabir Surya Tanaman Tunggal Berdasarkan Nilai \% Transmisi}

Nilai transmisi (T) merupakan cahaya yang tidak diabsorbsi oleh sampel, cahaya yang diserap diukur sebagai absorbansi (A). Semakin kecil nilai transmisi suatu sampel maka semakin banyak sinar diserap oleh sampel tersebut sehingga dapat dikatakan bahwa semakin kecil nilai transmisi suatu sampel maka semakin baik pula aktivitas tabir surya nya sampel tersebut (Aulia, 2017). Hasil pengujian dapat dilihat pada diagram 1 , diagram 2 dan diagram 3.

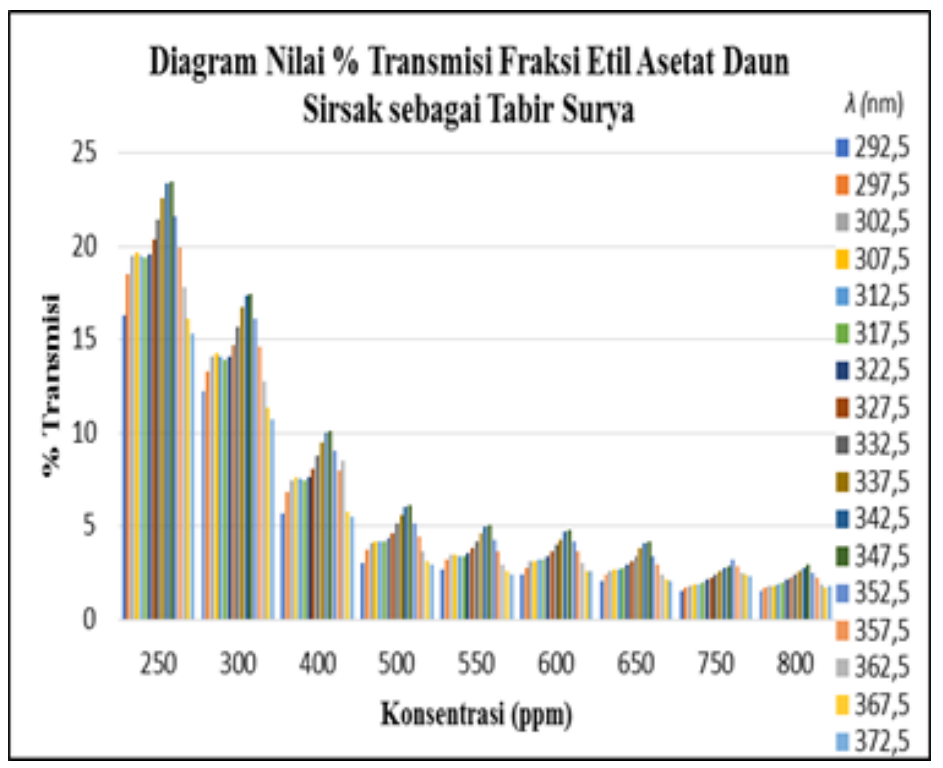

Diagram 1. Nilai \% Transmisi Fraksi Etil Asetat Daun Sirsak Sebagai Tabir Surya

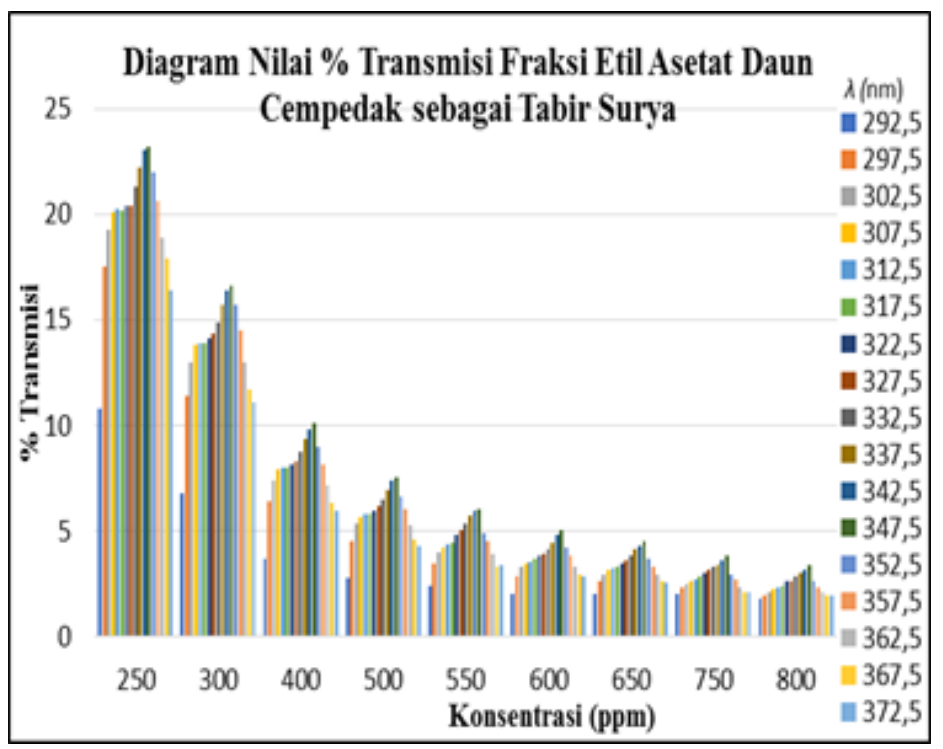

Diagram 2. Nilai \% Transmisi Fraksi Etil Asetat Daun Cempedak Sebagai Tabir Surya 
Uji Aktivitas Tabir Surya Kombinasi Fraksi Etil Asetat Annona muricata Linn Folium, Artocarpus champeden Spreng Folium dan Plectranthus scutellaroides Folium Secara In Vitro

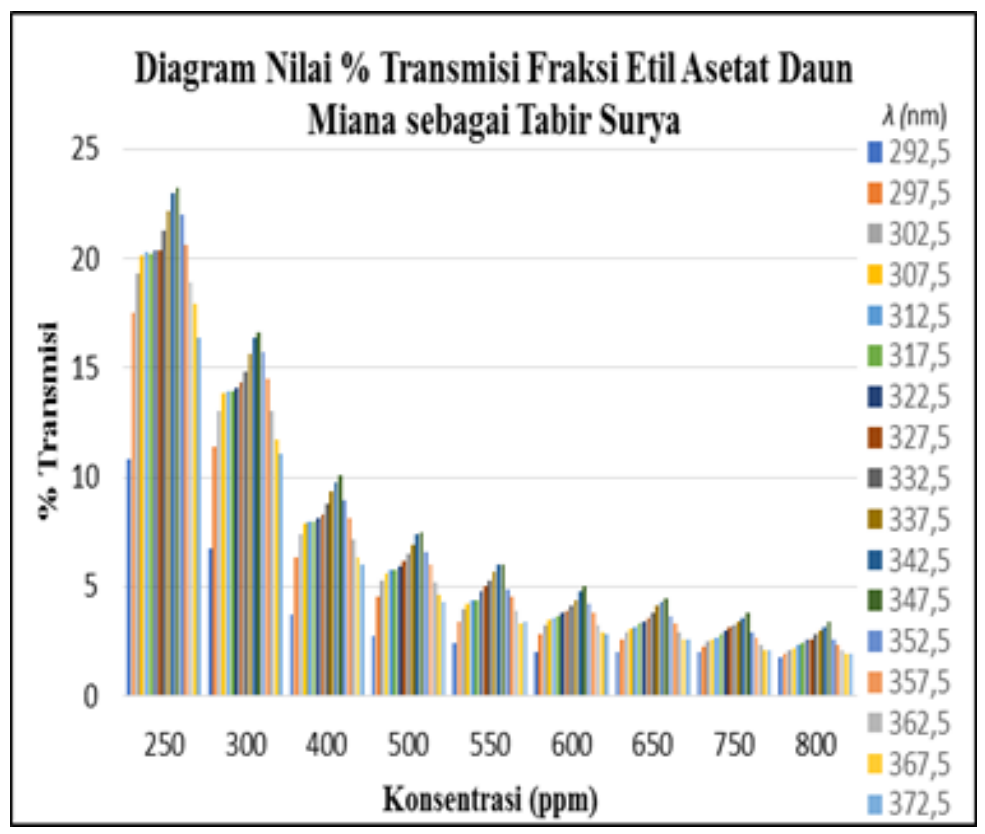

Diagram 3. Nilai \% Transmisi Fraksi Etil Asetat Daun Miana Sebagai Tabir Surya

Tabel 1. Nilai \%Te dan \%Tp Fraksi Etil Asetat Tunggal Daun Sirsak

\begin{tabular}{cccccc}
\hline Sampel & Fraksi Etil Asetat & $\% \mathrm{Te}$ & Kategori & $\% \mathrm{Tp}$ & Kategori \\
\hline Daun & $250 \mathrm{ppm}$ & 19,434 & Tidak ada & 18,146 & Sunblock \\
Sirsak & $300 \mathrm{ppm}$ & 14,082 & Fast tanning & 13,206 & Sunblock \\
& $400 \mathrm{ppm}$ & 7,492 & Suntan standar & 6,691 & Sunblock \\
& $500 \mathrm{ppm}$ & 4,154 & Proteksi ekstra & 3,633 & Sunblock \\
& $550 \mathrm{ppm}$ & 3,476 & Proteksi ekstra & 3,100 & Sunblock \\
& $600 \mathrm{ppm}$ & 3,179 & Proteksi ekstra & 2,774 & Sunblock \\
& $650 \mathrm{ppm}$ & 2,696 & Proteksi ekstra & 2,336 & Sunblock \\
& $750 \mathrm{ppm}$ & 1,946 & Proteksi ekstra & 1,690 & Sunblock \\
& $800 \mathrm{ppm}$ & 1,885 & Proteksi ekstra & 1,690 & Sunblock \\
\hline
\end{tabular}

Tabel 2. Nilai \%Te dan \%Tp Fraksi Etil Asetat Tunggal Daun Cempedak

\begin{tabular}{cccccl}
\hline Sampel & Fraksi Etil Asetat & $\%$ Te & Kategori & $\% \mathrm{Tp}$ & Kategori \\
\hline Daun & $250 \mathrm{ppm}$ & 19,080 & Tidak ada & 16,106 & Sunblock \\
Cempedak & $300 \mathrm{ppm}$ & 12,934 & Fast tanning & 10,559 & Sunblock \\
& $400 \mathrm{ppm}$ & 7,379 & Suntan standar & 5,918 & Sunblock \\
& $500 \mathrm{ppm}$ & 5,328 & Proteksi ekstra & 4,263 & Sunblock \\
& $550 \mathrm{ppm}$ & 4,082 & Proteksi ekstra & 3,296 & Sunblock \\
& $600 \mathrm{ppm}$ & 3,330 & Proteksi ekstra & 2,715 & Sunblock \\
& $650 \mathrm{ppm}$ & 3,008 & Proteksi ekstra & 2,516 & Sunblock \\
& $750 \mathrm{ppm}$ & 2,582 & Proteksi ekstra & 2,258 & Sunblock \\
& $800 \mathrm{ppm}$ & 2,214 & Proteksi ekstra & 2,258 & Sunblock \\
\hline
\end{tabular}


Uji Aktivitas Tabir Surya Kombinasi Fraksi Etil Asetat Annona muricata Linn Folium, Artocarpus champeden Spreng Folium dan Plectranthus scutellaroides Folium Secara In Vitro

Tabel 3. Nilai \%Te dan \% Tp Fraksi Etil Asetat Tunggal Daun Miana

\begin{tabular}{cccccc}
\hline Sampel & Fraksi Etil Asetat & $\%$ Te & Kategori & $\%$ Tp & Kategori \\
\hline Daun Miana & $250 \mathrm{ppm}$ & 5,175 & Proteksi ekstra & 4,553 & Sunblock \\
& $300 \mathrm{ppm}$ & 3,825 & Proteksi ekstra & 3,297 & Sunblock \\
& $400 \mathrm{ppm}$ & 3,646 & Proteksi ekstra & 3,251 & Sunblock \\
& $500 \mathrm{ppm}$ & 3,521 & Proteksi ekstra & 3,140 & Sunblock \\
& $550 \mathrm{ppm}$ & 3,444 & Proteksi ekstra & 3,043 & Sunblock \\
& $600 \mathrm{ppm}$ & 3,381 & Proteksi ekstra & 3,027 & Sunblock \\
& $650 \mathrm{ppm}$ & 3,157 & Proteksi ekstra & 2,849 & Sunblock \\
& $750 \mathrm{ppm}$ & 2,389 & Proteksi ekstra & 2,114 & Sunblock \\
& $800 \mathrm{ppm}$ & 2,222 & Proteksi ekstra & 2,114 & Sunblock \\
\hline
\end{tabular}

Berdasarkan hasil penelitian yang terlihat pada diagram 1, diagram 2 dan diagram 3 semakin tinggi konsentrasi sampel maka semakin kecil pula nilai \% transmisi dari fraksi etil asetat tanaman tunggal daun sirsak, daun cempedak dan daun miana. Maka dapat disimpulkan bahwa semakin tinggi konsentrasi maka semakin baik pula aktivitas tabir suryanya dilihat dari nilai transmisinya. Pada tanaman tunggal daun sirsak, daun cempedak dan daun miana berpotensi sebagai tabir surya

\section{Aktivitas Tabir Surya Tanaman Tunggal Berdasarkan Nilai \% Te dan \% Tp.}

Parameter dari aktivitas tabir surya dapat dilihat dari persentase transmisi eritema (\% $\%$ Te dan persentase transmisi pigmentasi (\% Tp) yang selanjutnya dapat dikategorikan sesuai dengan kategori profil tabir surya. Persentase transmisi eritema (\% Te) yaitu nilai persentase sinar yang diteruskan oleh sediaan tabir surya pada panjang gelombang sinar ultraviolet penyebab eritema pada panjang yaitu 292,5 - 372,5 nm. Persentase transmisi eritema (\% $\mathrm{Tp}$ ) yaitu nilai persentase sinar yang diteruskan oleh sediaan tabir surya pada panjang gelombang sinar ultraviolet penyebab pigmentasi pada panjang yaitu $292,5-372,5 \mathrm{~nm}$. Hasil pengujian dapat dilihat pada tabel 1, tabel 2 dan tabel 3 . Tujuan dilakukan pengujian pendahuluan aktivitas tabir surya tanaman tunggal adalah untuk mencari konsentrasi terbaik yang selanjutnya akan dikombinasikan.

Berdasarkan hasil penelitian yang dapat dilihat diatas diketahui kategori aktivitas tabir surya daun sirsak dan daun cempedak yang sama berdasarkan nilai \% $\mathrm{Te}$ dan \% $\mathrm{Tp}$ yaitu salah satunya konsentrasi daun cempedak $250 \mathrm{ppm}$ dan daun miana 250 ppm keduanya tidak termasuk dalam rentang kategori profil tabir surya berdasarkan nilai \% Te pada konsentrasi tersebut tanaman daun sirsak dan daun cempedak tidak dapat melindungi kulit dari eritema namun dapat mencegah terjadinya pigmentasi karena berdasarkan nilai \% Tp berpotensi sebagai sunblock. Diduga pada konsentrasi tersebut terlalu rendah konsentrasinya sehingga senyawa yang berada pada daun sirsak dan daun cempedak tidak dapat menyerap sinar UV dengan sempurna. Adapun pada konsentrasi berikutnya tanaman daun sirsak dan daun cempedak berdasarkan nilai \%Te berpotensi sebagai fast tanning, suntan standar dan proteksi ekstra dan berdasarkan nilai \% Tp sebagai sunblock. Sehingga dapat memberikan perlindungan pada kulit dari eritema dan pigmentasi khususnya konsentrasi di atas 500 ppm. Pada daun miana berdasarkan hasil pengujian pada tabel 3 diketahui berpotensi sebagai proteksi ekstra di semua konsentrasi uji. Sehingga dengan konsentrasi kecil saja daun miana dapat melindungi kulit dari eritema dan pigmentasi. 
Uji Aktivitas Tabir Surya Kombinasi Fraksi Etil Asetat Annona muricata Linn Folium, Artocarpus champeden Spreng Folium dan Plectranthus scutellaroides Folium Secara In Vitro

Tabel 4. Nilai SPF Tanaman Tunggal Fraksi Etil Asetat Daun Sirsak

\begin{tabular}{cccc}
\hline Sampel & Fraksi Etil Asetat (ppm) & Nilai SPF & Kategori Efektivitas Tabir Surya \\
\hline Daun Sirsak & $250 \mathrm{ppm}$ & 7,30 & Proteksi ekstra \\
& $300 \mathrm{ppm}$ & 8,47 & Proteksi maksimal \\
& $400 \mathrm{ppm}$ & 10,96 & Proteksi maksimal \\
& $500 \mathrm{ppm}$ & 13,19 & Proteksi maksimal \\
& $550 \mathrm{ppm}$ & 13,66 & Proteksi maksimal \\
& $600 \mathrm{ppm}$ & 14,39 & Proteksi maksimal \\
& $650 \mathrm{ppm}$ & 14,90 & Proteksi maksimal \\
& $750 \mathrm{ppm}$ & 16,26 & Proteksi ultra \\
& $800 \mathrm{ppm}$ & 17,01 & Proteksi ultra \\
\hline
\end{tabular}

Tabel 5. Nilai SPF Tanaman Tunggal Fraksi Etil Asetat Daun Cempedak

\begin{tabular}{cccc}
\hline Sampel & Fraksi Etil Asetat $(\mathrm{ppm})$ & Nilai SPF & Kategori Efektivitas Tabir Surya \\
\hline Daun & $250 \mathrm{ppm}$ & 6,97 & Proteksi ekstra \\
Cempedak & $300 \mathrm{ppm}$ & 8,36 & Proteksi maksimal \\
& $400 \mathrm{ppm}$ & 10,78 & Proteksi maksimal \\
& $500 \mathrm{ppm}$ & 12,85 & Proteksi maksimal \\
& $550 \mathrm{ppm}$ & 13,69 & Proteksi maksimal \\
& $600 \mathrm{ppm}$ & 14,00 & Proteksi maksimal \\
& $650 \mathrm{ppm}$ & 14,40 & Proteksi maksimal \\
& $750 \mathrm{ppm}$ & 14,91 & Proteksi maksimal \\
& $800 \mathrm{ppm}$ & 15,68 & Proteksi ultra \\
\hline
\end{tabular}

Tabel 6. Nilai SPF Tanaman Tunggal Fraksi Etil Asetat Daun Miana

\begin{tabular}{cccc}
\hline Sampel & Fraksi Etil Asetat $(\mathrm{ppm})$ & Nilai SPF & Kategori Efektivitas Tabir Surya \\
\hline Daun & $250 \mathrm{ppm}$ & 13,29 & Proteksi maksimal \\
Miana & $300 \mathrm{ppm}$ & 13,69 & Proteksi maksimal \\
& $400 \mathrm{ppm}$ & 13,95 & Proteksi maksimal \\
& $500 \mathrm{ppm}$ & 14,24 & Proteksi maksimal \\
& $550 \mathrm{ppm}$ & 14,31 & Proteksi maksimal \\
& $600 \mathrm{ppm}$ & 14,60 & Proteksi maksimal \\
& $650 \mathrm{ppm}$ & 15,76 & Proteksi ultra \\
& $750 \mathrm{ppm}$ & 16,23 & Proteksi ultra \\
& $800 \mathrm{ppm}$ & 17,01 & Proteksi ultra \\
\hline
\end{tabular}

Nilai SPF Tanaman Tunggal

SPF (Sun Protection Factor) merupakan satuan tabir surya yang dapat digunakan untuk menunjukan berapa lama kita bisa terpapar oleh sinar matahari tanpa kulit jadi terbakar (Sineke, 2016). Menurut Aulia (2017) nilai SPF (Sun Protector Factor) merupakan nilai perbandingan antara waktu yang diperlukan untuk terjadinya efek sengatan sinar matahari (sunburn) tanpa penggunaan tabir surya dan merupakan parameter dari efektifitas dari suatu bahan tabir surya. Hasil pengujian dapat dilihat pada tabel 4, tabel 5 dan tabel 6 .

Terdapat hubungan antara antara tabir surya dan nilai SPF dimana tabir surya menunjukkan mengenai potensi suatu sampel yang sebagai tabir surya untuk menyerap sebagian radiasi sinar UV 
A maupun UV B. Dan nilai SPF menunjukan berapa lama kita bisa terpapar oleh sinar matahari tanpa kulit jadi terbakar (Sineke, 2016). Potensi tabir surya dan SPF disebabkan oleh metabolit sekunder yaitu flavonoid. Hal itu dapat terjadi karena flavonoid memiliki gugus kromofor (ikatan rangkap tunggal terkonjugasi) mampu menyerap sinar UVA maupun UV-B sehingga mengurangi intensitas pada kulit (Rahmawati, 2012). Kategori nilai SPF yang terbaik yaitu proteksi ultra karena dapat melindungi kulit secara maksimal dari eritema dan pigmentasi

\section{Uji Aktivitas Tabir Surya Tanaman Kombinasi}

\section{Nilai \% Transmisi}

Sama halnya dengan aktivitas tabir surya tanaman tunggal pada aktivitas tabir surya tanaman kombinasi juga dapat dilihat nilai transmisinya. Nilai transmisi adalah banyaknya sinar yang tidak diserap oleh sampel. Pada tanaman kombinasi daun sirsak, daun cempedak dan daun miana terdapat beberapa perbandingan konsentrasi yang diuji yaitu perbandingan $3: 3: 2, \quad 2: 2: 1, \quad 1: 2: 2 \quad$ dan $1: 1: 1$. Perbandingan 3:3:2 merupakan perbandingan dengan konsentrasi 750 ppm daun sirsak, 750 ppm daun cempedak dan $500 \mathrm{ppm}$ daun miana. Perbandingan 2:2:1 merupakan perbandingan dengan konsentrasi 600 ppm daun sirsak, 600 ppm daun cempedak dan 300 ppm daun miana dan 500 daun sirsak, 500 daun cempedak dan 250 daun miana. Perbandingan 1:2:2 merupakan perbandingan dengan konsentrasi 500 ppm daun sirsak, 500 ppm daun cempedak dan 250 ppm daun miana. Dan perbandingan 1:1:1 salah satunya yaitu perbandingan konsentrasi daun sirsak 400 ppm, daun cempedak 400 ppm dan daun miana 400 ppm.

Pada diagram 4 merupakan hasil penelitian aktivitas tabir surya berdasarkan nilai \% transmisi dengan berbagai perbandingan konsentrasi kombinasi daun sirsak, daun cempedak dan daun miana yaitu $3: 3: 2,2: 2: 1,1: 2: 2$ dan 1:1:1 . Namun bisa dilihat pada diagram 4 tanaman kombinasi dengan perbandingan 1:1:1 merupakan perbandingan konsentrasi terbaik karena memiliki nilai \% transmisi yang rendah kecuali pada konsentrasi $250 \mathrm{ppm}: 250$ ppm : $250 \mathrm{ppm}$ tidak termasuk aktivitas tabir surya yang baik karena memiliki nilai \% transmisi yang paling tinggi namun tetap berpotensi sebagai tabir surya.

Pada diagram tersebut juga menunjukkan hasil penelitian aktivitas tabir surya dengan perbandingan lainnya yang dimana hasilnya nilai transmisinya tidak berurutan yang seharusnya semakin tinggi konsentrasi maka semakin kecil nilai transmisi hal ini diduga karena ketiga perbandingan konsentrasi kombinasi tidak dapat dijadikan menjadi satu kesatuan konsentrasi yang sama karena didalamnya terdapat tiga senyawa yang berbeda dari tanaman yang berbeda dan tidak dapat diurutkan konsentrasinya dari besar ke kecil.

\section{Aktivitas Tabir Surya Tanaman Kombinasi Berdasarkan Nilai \% Te dan $\% \mathrm{Tp}$ \\ Pada tanaman kombinasi} dilakukan pengujian aktivitas tabir surya dengan berbagai perbandingan yang bertujuan untuk mencari nilai aktivitas tabir surya yang terbaik di semua parameter tabir surya yaitu nilai $\%$ Te dan \% Tp yaitu sunblock. Hasil pengujian dapat dilihat pada tabel 7 .

Berdasarkan hasil penelitian diatas aktivitas tabir surya tanaman kombinasi dapat memenuhi target yaitu mencapai kategori sunblock berdasarkan nilai \% $\mathrm{Te}$ dan $\% \mathrm{Tp}$ yaitu pada perbandingan konsentrasi 1:1:1 dengan konsentrasi terbaik pada $400 \mathrm{ppm}: 400 \mathrm{ppm}: 400$ ppm, Hal ini sejalan dengan nilai transmisi yang dimiliki yang sangat kecil. 


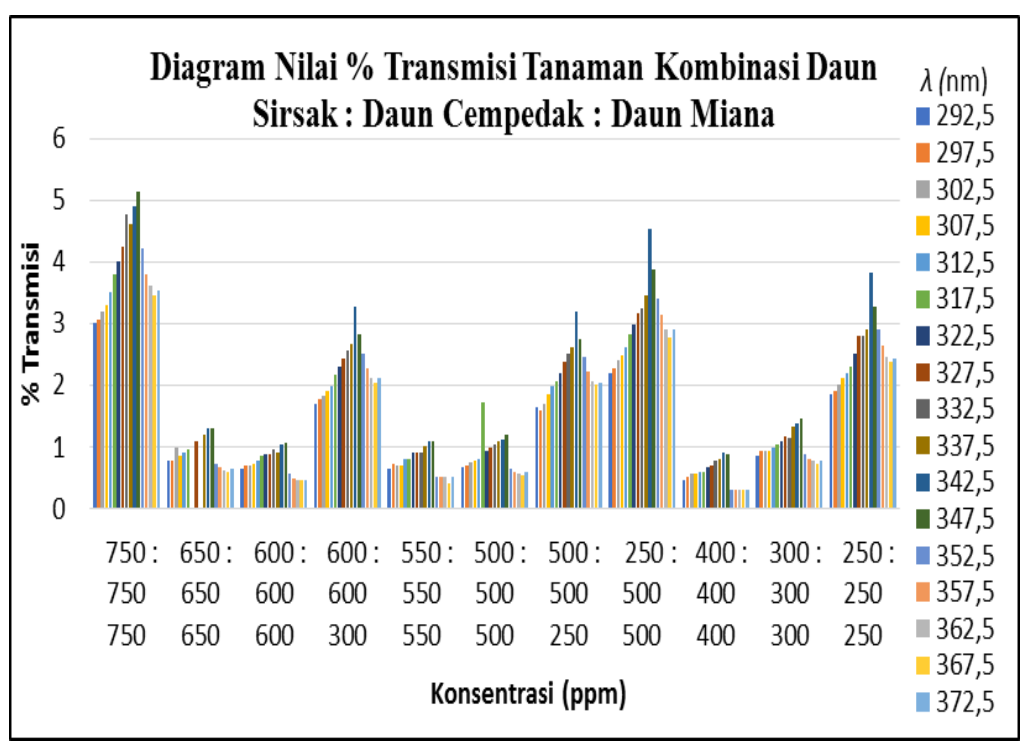

Diagram 3. Nilai \% Transmisi Tanaman Kombinasi Daun Sirsak, Daun Cempedak dan Daun Miana

Tabel 7. Aktivitas Tabir Surya Tanaman Kombinasi

\begin{tabular}{cccccc}
\hline Sampel & Fraksi Etil Asetat $(\mathrm{ppm})$ & \%Te & Kategori & $\% \mathrm{Tp}$ & Kategori \\
\hline Daun Sirsak & $750: 750: 500$ & 3.475 & Proteksi ekstra & 3,111 & Sunblock \\
Daun & $650: 650: 650$ & 0,926 & Sunblock & 0,830 & Sunblock \\
Cempedak : & $600: 600: 600$ & 0.737 & Sunblock & 0,687 & Sunblock \\
Daun Miana : & $600: 600: 300$ & 2.001 & Proteksi ekstra & 1,780 & Sunblock \\
& $550: 550: 550$ & 0.743 & Sunblock & 0,698 & Sunblock \\
& $500: 500: 500$ & 0.813 & Sunblock & 0,713 & Sunblock \\
& $500: 500: 250$ & 1,909 & Proteksi ekstra & 1,693 & Sunblock \\
& $400: 400: 400$ & 0.567 & Sunblock & 0,488 & Sunblock \\
& $300: 300: 300$ & 0.980 & Sunblock & 0,912 & Sunblock \\
& $250: 500: 500$ & 2.621 & Proteksi ekstra & 2,310 & Sunblock \\
& $250: 250: 250$ & 2.201 & Proteksi ekstra & 1,935 & Sunblock \\
\hline
\end{tabular}

Tabel 8. Nilai SPF Tanaman Kombinasi Fraksi Etil Asetat Daun Sirsak, Daun Cempedak dan Daun Miana Konsentrasi Terbaik

\begin{tabular}{cccc}
\hline Sampel & Fraksi Etil Asetat $(\mathrm{ppm})$ & SPF & Kategori \\
\hline Daun Sirsak : & $750: 750: 500$ & 14,48 & Proteksi maksimal \\
Daun Cempedak : & $650: 650: 650$ & 19,49 & Proteksi ultra \\
Daun Miana & $600: 600: 600$ & 24,47 & Proteksi ultra \\
& $600: 600: 300$ & 17,08 & Proteksi ultra \\
& $550: 550: 550$ & 22,87 & Proteksi ultra \\
$500: 500: 500$ & 20,05 & Proteksi ultra \\
$500: 500: 250$ & 16,72 & Proteksi ultra \\
& $400: 400: 400$ & 25,59 & Proteksi ultra \\
& $300: 300: 300$ & 18,49 & Proteksi ultra \\
& $250: 500: 500$ & 14,16 & Proteksi maksimal \\
& $250: 250: 250$ & 16,44 & Proteksi ultra \\
\hline
\end{tabular}


Yang menandakan bahwa sampel memiliki aktivitas tabir surya yang sangat baik. Sunblock merupakan kategori tabir surya terbaik karena mampu menahan sinar UV A dan UV B dalam bentuk penghalang fisik dan memproteksi secara total. Sunblock dapat mencegah eritema dan pigmentasi.

Pada ketiga tanaman kombinasi daun sirsak, daun cempedak dan daun miana Pada konsentrasi yang sama 1:1:1 senyawa tersebut akan saling berinteraksi dan menghasilkan efek yang sangat baik. Pada perbandingan konsentrasi yang berbeda yaitu $3: 3: 2,2: 2: 1$, dan $1: 2: 2$ aktivitas tabir surya tidak mencapai sunblock namun berpotensi sebagai proteksi ekstra, hal ini diduga karena metabolit sekunder yang berpotensi sebagai tabir surya dari konsentrasi besar dan kecil akan saling mempengaruhi dimana konsentrasi rendah akan mengganggu aktivitas dari konsentrasi yang lebih tinggi begitu pula sebaliknya.

Pada konsentrasi yang lebih rendah seperti pada konsentrasi 250 ppm daun sirsak : $250 \mathrm{ppm}$, daun cempedak : 250 ppm daun miana tersebut tidak mencapai kategori sunblock hal ini diduga senyawa-senyawa metabolit sekunder yang berpotensi tabir surya jumlahnya sedikit sehingga tidak dapat menyerap sinar UV dengan sempurna. Hal ini didukung oleh pernyataan M. Hidayat., dkk (2014) dengan dikombinasikannya tiga jenis tanaman yang masing-masing memiliki senyawa metabolit sekunder, akan saling berinteraksi. Dapat berefek potensial pada konsentrasi yang lebih rendah dan dapat juga berefek sebaliknya pada konsentrasi yang lebih tinggi yaitu saling melemahkan .

\section{Nilai SPF Fraksi Etil Asetat Tanaman Kombinasi}

Berdasarkan hasil penelitian yang dapat dilihat pada tabel 8. Nilai SPF dari semua perbandingan konsentrasi 1:1:1 dan 2:2:1 berpotensi sebagai proteksi ultra.
Sedangkan sisa perbandingan lainnya berpotensi sebagai proteksi maksimal. Faktor yang dapat mempengaruhi penentuan nilai SPF adalah perbedaan konsentrasi. Faktor ini dapat menambah atau mengurangi kemampuan untuk menyerap sinar UV (More,.dkk. 2013). Sama halnya dengan aktivitas tabir surya berdasarkan nilai \% Te dan nilai \% Tp, nilai SPF tanaman kombinasi juga dipengaruhi oleh zat aktif yang terkandung pada masing-masing tanaman daun sirsak, daun cempedak dan daun miana sebagai komponen utama. Adapun pada konsentrasi 400 ppm : 400 ppm : 400 ppm memiliki nilai SPF yang paling tinggi hal ini sejalan dengan kemampuannya sebagai tabir surya tanaman kombinasi yang tertinggi. Hal ini menandakan bila perbandingan $400 \mathrm{ppm}: 400 \mathrm{ppm}$ : 400 ppm memiliki waktu perlindungan yang lebih lama pada kulit untuk mencegah terjadinya kemerahan (eritema).

\section{KESIMPULAN}

Perbandingan yang baik bagi kombinasi fraksi etil asetat daun sirsak, daun cempedak dan daun miana adalah perbandingan 1:1:1 yaitu pada $400 \mathrm{ppm}$ : $400 \mathrm{ppm}: 400 \mathrm{ppm}$.

\section{DAFTAR PUSTAKA}

[1].Balsam, M. S., dan Sagarin, E. 1972. Cosmetics : Science and Technology $2^{\text {nd }} E d ., \quad$ Vol. 1-3. Interscience Publishers, Inc : New York.

[2].Cumpelik, B.S. 1972. Analitical Producedures and Evalution of Sunscreens. Journal of The Society Chosmetic Chemistry. 23 (3) 333-345. [3].Lingga, Lanny. 2012. Bebas Hipertensi Tanpa Obat. Jakarta: Agro Media Pustaka

[4].M, Hidayat., Soeng, S, Prahastuti., S, Patricia., T.H. dan K.A., Yonathan. 2014. Aktivitas Antioksidan dan Antitrigliserida Ekstrak Tunggal Kedelai, Daun Jati Belanda Serta Kombinasinya. Bionaturra-Journal 
Uji Aktivitas Tabir Surya Kombinasi Fraksi Etil Asetat Annona muricata Linn Folium, Artocarpus champeden Spreng Folium dan Plectranthus scutellaroides Folium Secara In Vitro

Imu-Imu Hayati dan Fisik. Fakultas Kedokteran. Universitas Kristen Maranatha. Bandung. ISSN : 14110903

[5].Rahmawati, Dwi. 2012. Kandungan Metabolit Sekunder dan Aktivitas Antioksidan Daun Cempedak dan Kulit Batang Cempedak (Artocarpus champeden Spreng). Skripsi. Fakultas Farmasi Universitas Mulawarman : Samarinda
[6].Sineke, U. F., Edi., dan Sri, S. 2016. Penentuan Kandungan Fenolik dan Sun Protection Factor (SPF) dari Ekstrak Etanol dari Beberapa Tongkol Jagung (Zea mays L) Pharmacon. Jurnal Ilmiah Farmasi. 5 (1) ISSN 2302-2493. 